\title{
The Representation of Women as Gendered National Subjects in Ottoman-Turkish Novels (1908-1923)
}

\section{Elif Gozdasoglu Kucukalioglu}

To cite this article: Elif Gozdasoglu Kucukalioglu (2007) The Representation of Women as Gendered National Subjects in Ottoman-Turkish Novels (1908-1923), Journal of Gender Studies, 16:1, 3-15, DOI: $10.1080 / 09589230601116109$

To link to this article: https://doi.org/10.1080/09589230601116109

Published online: 05 Apr 2007.

Submit your article to this journal $\llbracket$

Џ Article views: 210 


\title{
The Representation of Women as Gendered National Subjects in Ottoman- Turkish Novels (1908-1923)
}

\author{
ELIF GOZDASOGLU KUCUKALIOGLU
}

\begin{abstract}
In order to understand the ongoing production of gendered nation in Anderson's sense, which is mainly realized in the cultural domain, novels can play a significant role in terms of representing the imagined boundaries and functioning as mediums through which cultural difference is expressed. As mentioned by Jean Franco, the novel can be used as a means to work out imaginary solutions to different and conflicting problems through the representation of some imaginary figures. The aim of this article is to examine the representation of women's images in novels in the preRepublican (Ottoman-Turkish) and early Republican period (1908-1923) in order to analyze the formation of gendered national identity. Women's images in these novels offer important clues towards having a better understanding of the production of gendered nationhood and exploring the specific characteristics of Turkish nationalism such as Westernization, the notion of collective soul, women's sexuality, emancipation and education.
\end{abstract}

KEYWORDS: Imagination, gender, women's images, novel, nationalism, Westernization

This article attempts to analyze the making of women as gendered national subjects by focusing on women's images in novels in order to grasp the production of Turkish gendered nationhood (see Anderson, 1983 and Franco, 1998 for further discussion on the ongoing production of gendered nationhood). My main concern is to look at women's images in novels with the aim of investigating some characteristics of Turkish nationalism, which, in turn, will enable us to envisage more about the gendered dimension of this particular project. Attention will be paid to the works of some authors written in the period between 1908 and 1923: 1908 is an important date in terms of the processes for the formation of the Turkish nation-state because it marks the appearance of 'Young Turks' whose ideas played a significant role in the formation of the Turkish nation-state in the Ottoman Empire; 1923, however, marks the establishment of the Turkish Republic.

In the analysis of women's images, I examine the works of some canonical authors such as Halide Edib Adivar, Yakup Kadri Karaosmanoglu and Peyami Safa. In order to be more illustrative, it is worth mentioning briefly their autobiographies. Halide Edib Adivar

Correspondence Address: Elif Gozdasoglu Kucukalioglu, Department of Political Science, University of Bilkent, Ankara, Turkey; Tel.: + 903124422 066; Email:gozdas@ bilkent.edu.tr or egozdas@ hotmail.com

Journal of Gender Studies, Vol. 16, No. 1 March 2007, pp. 3-15

ISSN 0958-9236 Print/ISSN 1465-3869 $\quad$ (c) 2007 Taylor \& Francis

http://www.tandf.co.uk/journal DOI: 10.1080/09589230601116109 
(1885-1964), after graduating from Uskudar American College, started her professional life in 1908 by writing articles in different journals. She worked as a teacher of history and inspector at different high schools. She taught Western literature at university. During the War of Independence, she became an important female figure taking different positions in the struggle against the Allied Forces. After the War of Independence in which she took an active part, she became a defender of the emancipation of Turkish women. She spent a couple of years giving conferences at different universities and for some time, she lived abroad. When she came back to Turkey, she taught at Istanbul University as a professor. She was elected a deputy from Izmir in 1950 for the Justice Party. Yakup Kadri Karaosmanoglu (1889-1974), on the other hand, wrote many articles, novels and poems in different newspapers. He taught philosophy and literature in high schools. During the War of Independence, he traveled around Anatolia and supported the War of Independence through the articles he wrote. After the establishment of the Republic in 1923, he was elected deputy twice in the parliament between 1923 and 1934 and between 1961 and 1965. He became a member of the Constitutional Assembly after the 1960 military intervention. In addition to that, he worked as an ambassador in different countries. Peyami Safa (1899-1961), after working as a teacher, started publishing a newspaper called Yirminci Asir [Twentieth Century]. His career as a writer started with his novels written for this newspaper. He wrote many novels, articles and published many periodicals.

The most important criteria for choosing these writers is the fact that they can be regarded as representatives of the canon of Turkish nationalist literature. In this sense, they can be defined as system writers. Additionally, both Halide Edip Adivar and Yakup Kadri Karaosmanoglu were actively involved in political and social issues by being integrated into politics through different political and bureaucratic positions. The novels that I choose are selected through a reading of several examples written by these authors and those novels are found to be more reflective in terms of representing women as part of the nationalist discourse. Women's images in these novels offer important clues towards having a better understanding of the production of gendered nationhood and exploring the specific characteristics of Turkish nationalism such as Westernization, the notion of collective soul, women's sexuality, emancipation and education.

The article includes two sections. In the first section, I will examine the significance of women's images in the formation of Turkish nationhood. This part will be useful in understanding how the imagination of women as a part of gendered national collectivities in political, historical and social terms is closely connected with the making of women as gendered national subjects in the novels. The second section, however, will be devoted to the elaboration of women's images in the novels. I will attempt to reveal which themes are used in portraying the female heroes of these narratives. The themes that I explore in the examination of women's images such as Westernization, women's emancipation, sexuality and education occupy a central place in understanding the gendered dimension of Turkish nationalism.

\section{Women's Images in the Turkish Nationalist Project}

The Turkish nationalist project, based on the idea of modernization and secularization, was characterized mainly by the ideas of enlightenment, science and rationality. The idea of progress lay at the core of this particular nationalist project where women's position 
occupied a central role. The question of Turkish national identity was taken into consideration via the discussion of the position of women (Kandiyoti, 1991; Yegenoglu, 1998; Arat, 1997). The new secularist Turkish state, established in 1923, attempted to distance itself from the Ottoman Empire by projecting images of 'emancipated' women signifying the difference of the new state from its Ottoman-Islamic predecessor (Cinar, 2005 , p. 60). Connectedly, the public visibility of women and suffrage were considered as important steps that should be taken for the external image of the state as a modern nation. Women's bodies and their unveiled presence acquired an ideological meaning because rather than substance or women's autonomy, women had to look like the civilized women of modern nations but this civilized outlook should not be in conflict with the morality of the society. In this respect, women were expected to present a sexually modest picture which could only be realized by the erasure of their sexuality and which should be in harmony with patriarchal morality (Kandiyoti, 1987).

As Kandiyoti suggests, although the Kemalist reforms emancipated and literally unveiled women, all these necessitated 'compensatory symbolism and a new veil - that of sexual repression' (Kandiyoti, 1988, p. 47). Although veiling was removed, it was replaced by an invisible metaphoric veil, which was 'the veil of chastity' (Najmabadi, 1993). This new image of woman within the discourse of modernity was 'modern - yet modest' (Najmabadi, 1991, p. 66). In the construction of this 'new modern - yet modest' image of Turkish women, education played a significant role. The Republican reformers attached great importance to the education of women because the backwardness of women could not only retard society as a whole but it could form an obstacle to the process of the modernization of the nation. The idea was that women should be enlightened for the enlightenment of the nation but they should never forget their domestic roles of motherhood. In other words, education was not for the abolishment of patriarchal values but it was for the reinforcement of the patriarchal discourse (Arat, 1998).

What the Republican reformers aimed to create was a combination of conflicting images according to which the new Turkish woman was expected to make a balance between being modern with her education, her active participation in public and social life and her unveiled presence; and being traditional with her motherhood, her modesty and her attachment to family. In this constructed 'image' of the new woman, the erasure of her sexuality was of crucial importance in terms of representing the morality of the nation. As Kadioglu points out, women became 'stimulated images of modernity' (Kadioglu, 1994, p. 653).

\section{Women's Images in the Novels}

After briefly stating how women's images are constructed with respect to the Turkish nationalist project, in this part of the study I will focus on the formation of women's images in the novels and I will reveal which themes are used and which characteristics are emphasized in the representation of women's images in the novels.

\section{Westernization}

The first theme that is presented in the novels with regard to women's images is the idea of Westernization. Actually, this theme can be described as one of the central motifs remaining as a clue to understanding the main points, that are going to be discussed. 
Turkish literature can be taken into consideration as a sphere constructed on the main promises of the Republican ideology and on binary oppositions such as Orient-West, individual-society, being a la turca or a la franca (Kahraman, 2000, p. 49). In this respect, it might be argued that the fictional characters are not representative types but they are proposed as models showing how Westernization should be understood and what would be the negative aspects of Westernization in the case of its misinterpretation (Moran, 1983).

The most significant novel reflecting the dichotomy between the West and the East, the negative effects of Westernization and the understanding of Westernization as the adoption of its culture, is Kiralik Konak [Mansion for Hire] by Yakup Kadri Karaosmanoglu, first published in 1922. The events in Kiralik Konak take place in the years between 1906 and 1918 in an Ottoman mansion. The novel explains the erosion of morality in Turkish society as a result of over-Westernization through the example of the collapse of a big family. The owner of the mansion, Naim Efendi, lives with his daughter Sekine Hanım, his son-in-law Servet Bey and with his two grandchildren Seniha and Cemil. Contrary to Naim Efendi who was brought up according to Ottoman manners, Servet Bey was raised according to French manners and he has many troubles because of the contradiction between the life he lives and the way he was brought up. Seniha, who Servet Bey brought up in accordance with his ideas, is the principal female character of the novel. Seniha has great admiration for Europe like her father and this admiration causes her to feel alienated and unhappy. Thus, she frequently experiences nervous breakdowns. Her deep passion for Europe results in her running away from home. After spending some time in Europe, she lives as the mistress of Faik, an immoral man, in Paris for a certain period. Then, she returns to Istanbul as a fallen woman and becomes the mistress of rich men. At the end of the novel, the Ottoman mansion is left to rent. Naim Efendi moves from the mansion to another apartment. Seniha lives a corrupted life with different men.

In the novel, the female character Seniha is portrayed as a restless girl whose imagination is deeply influenced by thoughts of Europe. The narrator describes Seniha as follows:

The reason was that she was a girl whom the French would call a fin de siècle girl. The turn of the century is such a new model of society that in its internal and external being, it is free of all sorts of records, present and past, and is subject to the currents of the future in the making. Seniha would always look like the features in topical fashion magazines. Her body - young, fresh, slender and agile - was always in a constant metamorphosis like that of silkworms. Like her green eyes which would change conforming to the changing light of the day, the tune of her voice, the rhythm of her moves and even the way her head's pose would ceaselessly change. Her inner world was alike; she had a soul identical to the color of her eyes, now palpitating, full of sorrow, with a cloud over it, then wicked, clear, calm and as festive as fireworks. But if there was something fixed in her little devilish body that was her ironic and coquettish nature.

(Karaosmanoglu, 1983, pp. 16-17)

For Seniha, Westernization means money, having fun, fashion and rejecting all traditions. She appreciates anybody who visited Europe. Discussing with them and being with them not only ensure status but also give her a psychological pleasure. In fact, her 
relations with Faik, who grew up in Europe because of his father's job, are based on this kind of admiration.

In this novel, there is both the critique of the backwardness of Ottoman society in the personality of Naim Efendi and the moral corruption coming into existence as a result of the misunderstanding of Westernization in the personality of Seniha. Accordingly, the novelist criticizes the fact that people understand Westernization as practicing the manners and the customs of the West. In this way, the more they become a la franca (Westernized), the more alienated they become to themselves because they lose their own identity. They cannot find a place for themselves and they live in miserable conditions. In a way, they become so indifferent to their existence, to their society and to their culture that they get bored and they live in a state of annoyance - in a very big angoisse. This is well reflected in the character of Seniha who expresses her annoyance in the sentences below:

Do you think I will spend my life in such a house? In such a country with such people around me? Do you think I will lead a life in which I would only be able to own about half a dozen clothes a year, seldom go to Ada to pay a visit, and wait downstairs for a couple of meaningless and dull visitors on Mondays? No, Grandpa, I am not a girl of such simple soul! I read many, I learned a lot, I thought a lot and I made many analyses. I know that this thing called life is an endless field outside this prison where I have grown up since the day I was born; it is vast, full of sound, light, strange, full of joys and sorrows, flat, winding; it has its rises and falls.

(Karaosmanoglu, 1983, p. 110)

As can be understood from this quotation, she describes her alienation and this anxiety as 'a prison' and she expresses her reluctance to live in this space. In another part of the book, when she learns that a friend of her parents has gone to Paris, she is disappointed and regards her not going to Europe as incompetence. At this point, she explains her desperation and says:

I shall also decay like this garden. [... I I shall disappear one day, all of a sudden, and become invisible under a pile of dry leaves! One day, I will say 'how fast my youth went by!' as if I were saying 'How fast this season has passed by!

(Karaosmanoglu, 1983, p. 118)

The dream of Seniha and her dissatisfaction with the society where she lives, results in her corruption, and in this sense Westernization becomes a destructive force for those who misinterpret its meaning and who admire Western style of living and manners. Seniha, for whom the meaning of Westernization is clothes, shoes, stockings, automobiles and comfortable and tidy rooms, is an example of women who understand Westernization in cosmetic terms. Westernization is an important point of reference in understanding how women are expected to establish a balance between Turkish culture and Western civilization.

\section{Emancipation of Women}

Another important motif that appears in the novels with regard to the description of women as objects of nationalist discourse is emancipation of women. How is the importance of the emancipation of women treated in the novels? Seviyye Talip by Halide Edib Adivar, first 


\section{Journal of Gender Studies}

published in 1910, is an important novel in this respect where there is a strong emphasis upon the necessity of emancipating women and freeing them. The events of the story happen in the Second Constitutional Period (1908-1918). Fahir, the hero of the novel, comes back to the country after spending three years in England. When he returns, he starts criticizing his wife, Macide, for being too conservative and for not using her capacity enough. He argues that the lack of women's participation in public life is a national deficiency. At the beginning of the novel, Macide is presented as a very passive character strongly attached to her traditions. However, by the help of her husband's critiques, she turns out to be a wife that Fahir expects her to be. Towards the end of the novel, Fahir falls in love with Seviyye who is portrayed as an alafranga Westernized woman. He suffers so much from this love affair that he tries to commit suicide.

The necessity of the improvement of the status of women is a remarkable characteristic of this novel. Fahir's experiences in England and his observations about English women make him conclude that Turkish women should liberate themselves from the traditions and domestic life in order to be active members of society. In this process, Fahir considers himself, and other men who recognize Europe, responsible for making women emancipated. In one of the conversations with Macide, he expresses his views as follows:

Perhaps the future will provide schools, broad views, and strong opinions for the women of the coming generation, and perhaps different means of education will be available for them. But the gravest duty of those young people who have seen Europe is to awaken the women of our times, to prepare them for life and to encourage them to contribute to the progress of the nation.

(Adivar, 1987, p. 18)

However, when he analyzes Macide, he thinks that she is passive and she is very indifferent to the social and political situation of the country. He says:

I often wondered whether Macide owned a personality different from this tranquil, calm and rather dull one. But no! Those are such young girls that they are literate only enough to read the papers and write some letters; then they spend all their time in domestic chores. The most natural thing for them is to sew, to sweep, to clean up and to keep the house neat and tidy. [...] While you talk about the things you have contemplated, her neurotic eyes hunt for dust on the surface of furniture.

(Adivar, 1987, p. 12)

Women, in the image of Macide, are portrayed as being mainly preoccupied with their domestic duties and indifferent to social and political matters, specifically to their rights. Since the conditions of women are addressed as reflections of backwardness, the amelioration of women's conditions and women's rights are important components of development and modernization, but women should never forget their roles of motherhood and as educators of future generations. Although Western civilization must be accepted, it is of crucial importance to protect moral values and social customs, and never imitate the West in terms of these values. Fahir states:

First of all, it should be explained that imitations, examples of which we have regretfully seen, have nothing to do with novelty; a woman to accept novelty does 
not have to be an exact copy of a French or English woman, and men needn't be modelled on the Parisian men either. We are not to ape another nation. We will be the new Turks who have been matured, who have put the humanitarian views into practice, who have accepted the development of the West and still remained loyal to the natural tendencies of its race in all sense of the word.

(Adivar, 1987, pp. 40-41)

What is suggested mainly by the words of Fahir is the idea that although the emancipation and the education of women are encouraged, this should be a controlled emancipation whose limits are prescribed by a male system of values. In the construction of women as national subjects, the male voice and the male oriented attitudes are dominant and women representing 'the other' do not have an identity in their own rights but they are constructed by different meanings that men choose. As can be seen in Fahir's example, it is the duty of the male hero to declare how women should be, to decide what is good for women and for society, and to show what are culturally designated as feminine characteristics.

\section{Women as Active Participants in the War}

The representation of women as active participants in the War of Independence in the novels is another important theme connected with the idea of change in the position of women and their sociability in public life. The ideal of socially and politically active women in the novels is symbolized by the portrayal of women's images as 'nationalist heroines'. By nationalist heroines, I mean the illustration of women who are involved actively in the War of Independence and in nationalist issues. The best examples of this new image of women as 'active participants to the National War' can be found in the novels of Halide Edib Adivar. The female characters in her novels reflect the image of ideal Turkish women who are impatient to work for the betterment of their society and for the future of the Turkish nation by being actively involved in public life.

Atesten Gomlek [The Shirt of Fire] by Halide Edib Adivar, published in 1922, explains the efforts and struggles of the Anatolian people against the Allied Forces. It is a significant novel where the main female character, Ayse, is portrayed as an important female figure identified with nation. The novel reflecting mainly the atmosphere of the War of Independence is fictionalized through the diary of Peyami who is staying at a hospital in Ankara at the time after having lost both of his legs in the Battle of Sakarya. Cemal and Ayse are the children of Peyami's uncle and when her mother wants Peyami to marry Ayse, Peyami runs away to Europe. Then, Ayse gets married to another man and settles in Izmir. Many years later, her son and husband are killed during the invasion of Izmir by Greek soldiers so that Ayse comes to Istanbul and stays at Peyami's house for a while. At this time, she becomes strongly interested in the national movement started in Anatolia to drive the Allied Forces from the country. Her older brother Cemal and his friend Major Ihsan actively fight against the enemies. When Istanbul is occupied by the British, she comes to Anatolia and participates actively in the war effort by working as a nurse. In the meantime, although Ayse and Major Ihsan love each other, national love and defeat of the enemies take priority over their love. At the end of the novel, Major Ihsan, Cemal and Ayse all die. Peyami, who is also in love with Ayse, also dies later in a hospital in Ankara. 
Ayse symbolizes one of the women who puts on the 'shirt of fire' by taking part actively in different phases of the National War with different social roles. She represents a brave woman who becomes a heroine among the Anatolian people during the War of Independence. She is so courageous that when she meets an English man, she talks about the cruelty of the Allied Forces occupying the country without any hesitation. Halide Edib Adivar describes Ayse's courage as follows: 'She was also awakening the respect and the excitement that the black flags at the minarets were arousing' (Adivar, 1978, p. 31). In this description, there is the identification of nation with woman and this identification is also evident in various parts of the novel. In one of her letters, Ayse says:

Oh my God! Because he had sworn at an English woman, an Indian was made to walk on hands like animals by the English men. Shan't our army have the same desire to punish those who cannot stand for the grandeur of Turkish woman and make her crawl? Don't they think that an insult to their women is one to their flag?

(Adivar, 1978, p. 59)

Ayse fights with the other male heroes of the novel against the enemies in Anatolia. In a way, she puts on this 'shirt of fire' like men. She cares for injured persons, she nurses during the National War and she cheers the soldiers escaping from İstanbul. Her main objective is to take an active role in the War of Independence and thus, to be able to serve the nation. Sometimes, she criticizes the men who attempt to protect her, by declaring 'whom I hate the most are those who want to protect me and keep me like an object to be kept safe on shelves' (Adivar, 1978, p. 86). As clearly seen in these sentences, Ayse is portrayed as a woman who does not want to be considered as 'an object' but as 'a human being'. The image of women as active participants in social and political issues emerges as an important signifier for representing 'the new Turkish woman' who becomes a part of the Turkish national collectivity.

\section{Educated Women}

The enlightenment of women is a remarkable motif treated in most of the novels with regard to women's images. An educated woman is not only an 'enlightened' one freeing herself from the conservatism of religious constraints, traditions and superstitions but she is also a 'knowing subject' who could play a significant role in the future of society by being an equal partner with men. The heroines in Handan by Halide Edib Adivar, first published in 1912, exemplify the significance of education and of being 'an enlightened woman' for the well being of society. At the beginning of the novel, Refik Cemal, the male hero of the novel, writes to his friend that he is going to marry Neriman who is not a welleducated woman. Although Refik Cemal defines Neriman as a 'good girl', he is not happy at all about her indifference to the social and political problems that the country faces. Handan, one of Neriman's female cousins, however, is a woman who is not only well educated but who also has a deep passion for learning about political and social things. Refik Cemal meets Handan during a journey in France. Her intellectual level and her knowledge on several issues influence him to a large extent. Handan's husband, Hüsnü Paşa, a retired ambassador, betrays her with different women but Handan remains always faithful to her husband though she has some feelings for Refik Cemal. At the end of the novel, she dies from meningitis. 
At the beginning of the novel, Refik Cemal criticizes his wife, Neriman, for her seclusion at home and for not being interested in anything outside the home. In the eyes of her husband, Neriman is a very good wife, mainly occupied with domestic duties but she is not well educated and more importantly, she is indifferent to what Refik Cemal reads. She doesn't like sociology, history and philosophy. Therefore, her husband describes her like 'a plant, a flower'. He says:

Neriman likes music a lot, she plays the piano well, she has a sweet and smooth singing voice. But it is just a dream to see her as a comrade who would share the male ideals burning our souls; she is not like everybody, a soul raised in this country; she is a plant, a flower, and a thing! However bitter, dark and weak it may be, the life in the country is of nothing to her. I cannot make her share with me this huge but desperate thing that occupies me much. What I cannot find in Neriman is this. She cannot understand why I juggle with such things which she finds rather theoretical.

(Adivar, 1995, pp. 25-26)

As seen in the example of Fahir in Seviyye Talip who underlines the importance of the emancipation of women, another male hero, Refik Cemal, defends the necessity of education for women. In one of his letters to his wife, Refik Cemal expresses his admiration for Handan who portrays an educated woman in these words:

Handan and I talked about everything, Neriman; about those topics that put you to sleep such as sociology, economics, philosophy and even politics. The femininity of her bright eyes and of her brilliant hair gradually flew away before my eyes; I ceased to see her delicate white bosom. [ ... ] This is so strange, Neriman. Your cousin and I have got such matching minds and we opened them to each other as two very close friends.

(Adivar, 1995, p. 38)

Again, we come across an appreciation of Handan by Refik Cemal. By saying 'Your niece and I have got such matching minds', he declares the necessity of the education of women in order to be equal partners with men. Although Neriman is portrayed not as an intellectually mature woman, the image of 'enlightened woman' appears in the character of Handan who has a deep interest in intellectual matters. She is an intelligent woman, interested in different fields such as economics and philosophy. Neriman, in one of the letters to her husband, says:

She has an ever-thirsty mind that wants to know, always know not only the things in books, but those in nature, in people, in everything, and the things invisible. But that is not the dry brain of those intellectual women, Refik! She has in her the affection that loves and embraces the things she knows; she has the heart of a woman.

(Adivar, 1995, p. 42)

As can be seen clearly in the image of Handan, the capacity and the education of women should not be in conflict with the constructed image of womanhood and femininity which symbolizes fragility and softness. The remedy for 'the dry brain of those intellectual women' is tenderness which is one of the essential properties of womanhood. To put it differently, there is a strong emphasis upon the notion of softness and delicateness all of 
which are attributed to women. Although the education of women is necessary to make them equal subjects of the Turkish nation, women should never forget what makes them women, in other words, their female characteristics.

\section{Women's Sexuality and Punishment of Women}

Another important theme in the novels connected with the representation of women's images is women's sexuality which is identified with the idea of chastity and the protection of honor. The most important criterion between 'good' and 'bad' female characters in the novels is their 'success' in representing their asexualized bodies. There is a parallelism between the portrayal of ideal woman and the erasure of her female sexual markers. In this sense, one can argue that the female body becomes degendered into a neutral body.

This can be observed in Sozde Kizlar [So-Called Girls] by Peyami Safa, first published in 1923. The events take place during the War of Independence when some places have been invaded by Greek troops in 1918. Mebrure, the heroine of the novel, comes to Istanbul in search of her father who has been captured by the Greeks. She starts staying in the house of Nazmiye Hanim who is one of her distant relatives. Nazmiye Hanim lives together with her daughter Nevin and her son Behic. Nevin is a woman who is mainly preoccupied with her beauty. Behic, on the other hand, presents himself with lots of compliments directed towards Mebrure and woos her from the moment she arrives to the house. The residents of this house lead a very different life compared to that of Mebrure. The parties arranged in the mansion house, in which guests consume alcohol, represent a different sort of life style for Mebrure who tries to remain away from such ways of living as much as she can.

From time to time, she goes to Muhacirin (the foundation related with the migrators) with the hope of finding her father. Nadir, whom she meets at Nazmiye's house, and Fahri, a friend of Nadir's, help her. Fahri is a pure and clever man and he is as ardent in the national struggle as Mebrure. At the end of the novel, Behic is arrested for having killed his own child by one of the girls he has been seeing. Belma, giving birth to this child, commits suicide. As for Mebrure, she gets ready to go to Anatolia together with Fahri after she finds a trace of her father.

The female characters in Sozde Kizlar such as Nazmiye Hanim, Nevin or Belma - in the writer's terms, 'so-called girls' - are the sort of women who may do anything once they turn out to be free and independent (Safa, 1993, p. 113). They all represent the degradation of society. For example, Nevin wants to marry Siyret, one of Behic's friends, so much that she even ignores his love affairs with other women. Belma, on the other hand whose real name is Hatice, wants to be an actress. Although she is the daughter of a traditional family, she is an example of an over-Westernized woman who not only changes her name but also forgets the cultural customs of her society. Nazmiye Hanim, on the other hand, has a love affair with Belma's brother. These 'so-called girls' do not represent the ideal Turkish women because they only exist with their sexuality and femininity. In a sense, they are 'bad' because they cannot get rid of their sexuality and cover their femininity.

The most remarkable similarity of this novel with the previous one Seviyye Talip is the fact that when Mebrure comes from her village to a big city, Istanbul, her dressing habits undergo changes; she is not veiled any more and she wears the same style as other Westernized women. She puts on long décolleté dresses but she remains chaste and virtuous. She represents naivety, naturalness and rationality while others symbolize the demoralization of society and impurity. There is a sudden change in the physical appearance of Macide in Seviyye Talip and Mebrure in Sozde Kizlar but they remain faithful to their morality. Although the authors articulate their 
views for the improvement of women's lives which is necessary for a modern nation, they also try to idealize female chastity. For another time, we come across the attempt to synthesize the East and the West. The clothes and the visual appearance of women are important indicators symbolizing the existence of a modern Turkish nation but female chastity is viewed as essential to social stability.

Another important point related to the theme of women's sexuality is the fact that female characters who have sexual relations and who use their femininity are portrayed as 'over-Westernized women'. The over-Westernized women who use their sexuality are not only described as 'loose' and 'vulgar' but they are also depicted as 'ignorant' and 'uneducated'. Chaste women, however, are enlightened ones. What is remarkable in the personification of these chaste women and in the idealization of 'asexualized women' is that the images of 'enlightened and educated women' representing wisdom and knowledge are characterized as the antithesis of 'vulgar women'. There is always a tendency to identify 'unchaste' women as women who are ignorant, who are indifferent to the political and social problems that the country faces and who never question any subject.

In Sozde Kizlar, Mebrure represents 'the essential Turkish girl'. She not only symbolizes feminine virtues such as self-sacrifice, virtue, chastity and purity, but at the same time, she is interested in the political problems of the country, and especially in the War of Independence. This, in turn, makes her different from other 'so-called girls' who are mainly occupied with their beauty and their physical appearances and who are indifferent to the national war and to other social and political problems that their country faces. For example, Nevin, characterized as an 'over-Westernized woman', says at a party: 'War, invasion, heavy cannonballs are of no interest to us! We are not trained to fight. It does not fall to us to deal with such things, does it?' (Safa, 1993, p. 52). These women are portrayed by the writer as loose, sexually promiscuous, immoral and of easy virtue because they use their sexuality in their personal relations and as mentioned above they are illiterate. Although they are women of a country occupied by foreign forces, they are represented as alienated to their nation and to their society. This seems to me very expressive because the writer tries to construct the woman as an asexual being. The more she is asexualized, the more she is virtuous and enlightened. The more she is purified from sexual desires, the more socially active she is.

What is interesting in the representation of the 'bad' and 'over-Westernized' women who do not succeed in being 'virtuous goddesses' is the fact that they are subject to different punishments. They die, they become mentally ill or they disappear from the scene. Belma in Sozde Kizlar, for example, commits suicide by poisoning herself when her lover refuses to marry and forces her to have an abortion. Seniha in Kiralik Konak becomes mentally ill. In Seviyye Talip, Seviyye also commits suicide at the end of the novel. These women's images are portrayed as being partly responsible for the moral corruption and degeneration of society; and to some extent, they are contrary to the ideal figures of women who exist for the well-being of society and not for their pleasure.

\section{Conclusion}

Women as gendered national subjects are created as a part of the collective identity and as a reflection of the notion of 'collective soul' in the novels. The conflict between 'good' and 'bad' female characters forms an important part of the fiction where the author definitely encourages the former and punishes the latter. The good ones are portrayed as models 
symbolizing the idealized Turkish women; however, the 'bad' ones who represent an anomaly to the 'collective soul' by their individual behaviors and, most of the time, by their perception of morality, are punished by the writers. In this respect, it might be argued that female characters are expected to serve the enforcement of the idea of organic solidarity.

In observing women's images, we come across the fact that women characters have a double position; on the one hand, women have a 'subject' position according to which they are portrayed as socially and politically active participants in the nationalist issues. With their education and their visibility in public space, they symbolize speaking subjects representing modern Turkish women who can play an active role in the formation of Turkish national collectivity. On the other hand, they have an 'object' position according to which they are expected to protect the 'inner' domain of the national collectivity as being carriers of the moral rules and traditions. The most important condition for symbolizing the morality of the national collectivity is the erasure of their sexuality. The image of the ideal woman is constructed as an 'asexualized woman' who is able to cover her femininity and her sexual identity in order to be equal to men.

Upon my analysis on women's images in those novels, it is possible to conclude that the images of women as presented in the novels prepare the ground for the reinforcement/reimagination of women's 'stimulated images' of the Turkish Republic. Women's images in the novels significantly contribute to what the Turkish nationalist project attempts to construct with regard to women. In this respect, it might be argued that women's images in fiction play a significant role in strengthening the formation of Turkish gendered national identity. The images of women who are hardworking, socially active, educated and chaste, who leave their femininity aside, and who appear as mothers of the nation representing the honor of the national collectivity, are identified with the main goals of nationalism.

A final remark that should be made with regards to this is the following. The imagination of women in political and social terms and the imagination of women as gendered national subjects in cultural texts are closely connected with each other. Cultural texts produce fictive women whose representation symbolizes 'real' and 'idealized' women. Women are fictive and their presentation is also fictive, but they portray gendered national subjects. The imagination of women in political terms also presents the fiction because nations are a blend of fictive imagining. Women are present in this imagination in different spheres by performing different roles. They create the borders for the brotherhood but they remain absented from the fraternity characterized by men. For that reason, their representation defines them fictively. The fiction is not the case only in the novels or in different literal texts but in real politics, women's representation produces fiction. Women lose their own identity because their identity is imagined as a marker for the nation and their status is closely connected with the progress of the nation. In Eisenstein's terms, 'women become a metaphor for what they present rather than what they are' (Eisenstein, 2000, p. 43).

\section{References}

Adivar, H. E. (1978) Atesten Gomlek [The Shirt of Fire] (Istanbul: Atlas).

Adivar, H. E. (1987) Seviyye Talip (Istanbul: Atlas).

Adivar, H. E. (1995) Handan (Istanbul: Atlas).

Anderson, B. (1983) Imagined Communities: Reflections on the Origin and Spread of Nationalism (New York: Verso). 
Arat, Y. (1997) The project of modernity and women in Turkey, in: S. Bozdogan \& R. Kasaba (Eds) Rethinking Modernity and National Identity in Turkey (Seattle: University of Washington Press).

Arat, Z. (1998) Educating the daughters of the Republic, in: Zehra Arat (Ed.) Deconstructing Images of 'the Turkish Woman' (New York: St. Martin's Press).

Cinar, A. (2005) Modernity, Islam and Secularism in Turkey (Minneapolis: Minnesota Press).

Eisenstein, Z. (2000) Writing bodies on the nation for the globe, in: S. Ranchod-Nilsson \& A. M. Tétreault (Eds) Women, States and Nationalism: At Home in the Nation? (London \& New York: Routledge).

Franco, J. (1998) The nation as imagined community, in: A. McClintock, A. Mufti \& E. Shohat (Eds) Dangerous Liaisons: Gender, Nation and Colonial Perspectives (Minneapolis: University of Minnesota Press).

Kadioglu, A. (1994) Women's subordination in Turkey: is Islam really the villain?, Middle East Journal, 48, pp. 645-660.

Kahraman, H. B. (2000) Cumhuriyet Edebiyati Epistemolojisi: Kisitlamalar ve Bir Yaklasim Onerisi [Epistemology of the Republican literature: limitations and an approach proposal], Varlık, 2, pp. $45-54$.

Kandiyoti, D. (1987) Emancipated but unliberated? Reflections on the Turkish case, Feminist Studies, 13, pp. $317-338$.

Kandiyoti, D. (1988) Slave girls, temptresses, and comrades: images of women in the Turkish novel, Feminist Issues, 8, pp. 35-50.

Kandiyoti, D. (1991) Women, Islam and the State (London: Macmillan).

Karaosmanoglu, Y. K. (1983) Kiralik Konak [Mansion for Hire] (Istanbul: Iletisim).

Moran, B. (1983) Turk Romanina Elestirel Bakis [A Critical Approach to the Turkish Novel] (Istanbul: Iletisim).

Najmabadi, A. (1991) Hazards of modernity and morality: women, state and ideology in contemporary Iran, in: D. Kandiyoti (Ed.) Women, Islam and the State (London: Macmillan).

Najmabadi, A. (1993) Veiled discourse - unveiled bodies, Feminist Studies, 19, pp. 487-518.

Safa, P. (1993) Sozde Kizlar [So-Called Girls] (Ankara: Imge).

Yegenoglu, M. (1998) Colonial Fantasies: Towards a Feminist Reading of Orientalism (Cambridge: Cambridge University Press). 